\title{
TODOS SOMOS ARTISTAS; TODOS SOMOS MANIQUIEES. O SOBRE EL NARCISISMO EN EL MUNDO CONTEMPORÁNEO
}

\section{LUIS D. RIVERO MORENO}

Universidad de Granada

Resumen: Gran parte de la necesidad humana de representación de su propia figura se ha vertido en la construcción de dobles en tres dimensiones. El maniquí será uno de los más utilizados en el ámbito artístico desde las primeras vanguardias. Planteado no sólo como sustituto sino competidor, adquirirá una autonomía que hace al hombre caer en la duda sobre la vitalidad de semejantes figuras. Tras ello quizás no esté más que el deseo de proyección de vida en un "otro" sobre el que autorretratarse. La personalidad artística de Narcissister pone al descubierto esa necesidad onanista de vernos reflejados en toda superficie.

Palabras clave: cuerpo en el arte, figura humana en el arte, maniquí, Narcissister, autorretrato.

Abstract: Most of human need for representation of his own figure has gone into the construction of doubles in three dimensions. Mannequin will be one of the most used in art since the first avant-garde. Being considered not just as a substitute but a man competitor, acquiring an autonomy that makes man fall into doubt about the vitality of such figures. After all there is nothing more than the desire to project life in an "other", a figure where every artist and viewer is portrayed. The artistic personality of Narcissister reveals the masturbatory need to see ourselves reflected in every surface.

Keywords: body in art, human figure in art, mannequin, Narcissister, self-portrait.

Resumo: A maior parte da necessidade humana de representação da sua própria figura tem ido para a construcão da dupla em três dimensões. O manequim será um dos mais utilizados nas artes desde as primeiras vanguardas. Considerado não apenas como um substituto mas como um concorrente, a sua autonomia faz ao homem cair na dúvida sobre a vitalidade de semelhantes figuras. Depois de tudo isso está o desejo de projetar a vida num "outro", no qual cada artista e espectador se retrata. A personalidade artística Narcissister revela a necessidade onanista de nós ver reflectidos em todas as superfícies.

Palavras-chave: arte corporal, figura humana na arte, manequim, Narcissister, auto-retrato.
We are all artists; we are all dummies. Or on narcissism in the contemporary world

Todos nós somos artistas; todos nós somos manequins.

Ou sobre o narcísismo no mundo contemporâneo 


\section{Introducción}

Todo arte que trate de acercarse a la figura humana lleva implícito una serie de cuestiones sutiles e intrincadas sobre el problema de la creación y la percepción. Un artista crea y un espectador mira una obra que, al tener forma humana, genera una compleja red de relaciones retratísticas y especulares. En la producción de figuras humanas se generan "dobles", pero aún más, dobles múltiples, pues reflejan al autor y a todo público que se acerque a ellas. Lo que nosotros vemos también nos mira, produciendo una reciprocidad que alimenta una comunicación a varias bandas al mismo tiempo que una escisión del ser en el acto estético de mirar y ser mirado ${ }^{1}$. El bucle parece de difícil solución, pues se reactualiza y subjetiviza en cada mirada, haciendo del análisis objetivo de la cuestión toda una odisea. Artista y público vierten recuerdos y experiencias personales al enfrentarse a lo humano. ¿Es el doble nuestro autorretrato y el de todos los demás al mismo tiempo?

El doble no debe ser entendido tan sólo como imagen, como mera representación, sino que adquiere un rol activo, tiene cometidos que realizar. Tiene además una "presencia" física en la mayor parte de los casos en tres dimensiones. Se mueve en una paradójica posición entre lo tangible y la referencia de aquello ausente. Nos permite poseer algo que realmente nunca será nuestro. Según Castro Flórez: "En cuanto presencia, el objetofetiche, es en efecto algo concreto y hasta tangible, pero en cuanto presencia de una ausencia es, al mismo tiempo, inmaterial e intangible, porque remite continuamente más allá de sí mismo hacia algo que no puede nunca poseerse realmente" ${ }^{\prime 2}$. Será esa ausencia quizás la que provoque que el doble se nos escape y sea capaz de adquirir una cierta autonomía. Así irá logrando poco a poco movimiento e identidad $y$, con ello, una vida propia que genera una creciente inquietud. Ya no está atrapado al otro lado del espejo, convive y se relaciona con nosotros en el mundo real. De la inquietud al siguiente paso, el miedo, hay una leve distancia. El doble ha sido creado para sustituirnos, por lo que tememos que si demuestra una cierta eficiencia realizando sus funciones terminemos siendo nosotros, sus modelos, los que tornemos innecesarios. Si éste terminara por ser capaz de ejecutar tareas mejor que su "original", ¿no correría el ser humano el peligro de verse relegado a sustituto?

El retrato, el reflejo, la huella, el monstruo... todo aquel "otro" humano genera un cierto malestar, una repulsión, al mismo tiempo que una fascinación. Tenemos la impresión de que, al girarnos, ese otro inerte volverá a la vida, que tan sólo ha fingido quietud para pasar desapercibido. En ocasiones imaginamos que un retrato pictórico pareciera seguirnos con la mirada; que el reflejo en nuestro espejo no ha repetido nuestros movimientos exactos al otro lado. Pensamos por momentos que, si adquiriera voluntad, no estaría allí parado ni se dedicaría eternamente a esperar nuestra presencia e imitarla. Las tres dimensiones multiplican esta sensación, la figura ya no sólo "parece", sino que de alguna manera "es", o, al menos, es física, tangible. Un leve movimiento a la altura del pecho demostraría que esa figura respira, vive. Pero al cerciorarnos y tocarla comprobamos que está fría, está hueca, se mantiene inexpresiva, con la mirada perdida. Algunos artistas hiperrealistas como Duane Hanson o Ron Mueck han profundizado en estas dudas generadas por la verosimilitud de sus figuras y la distancia a la que el espectador las observa. Incluso con la confusión que su observación descontextualizada a través de fotografías pudiera producir.

1. Idea general que ronda el estudio de DIDI-HUBERMAN, G.: Lo que vemos, lo que nos mira. Buenos Aires, Manantial, 2010.

2. CASTRO-FLÓREZ, F. en BORDES, J; CASTRO FLÓREZ, F.: Corpus meum, in anima tua. Salamanca, Ediciones Universidad de Salamanca, 2004, p. 22. 
Mueck, consciente de este hecho, terminaría eligiendo la opción de crear figuras a diferentes escalas, convertidas en miniaturas o gigantes, quizás temeroso de que éstas fueran tan cotidianas como las que nos cruzamos en las calles en nuestro día a día.

A este respecto uno de los problemas fundamentales con los que nos encontramos será derivado de la prohibición del museo y la exposición tradicional a tener una experiencia sensorial de la obra más allá de la ofrecida por el sentido de la vista. En ese caso, la duda seguirá en el aire. Como nos avisa Victor Stoichita:

"Cuando -hace más o menos tres siglos- las obras de arte se confinaron en los museos, esta prohibición vino a colmar su proscripción. De esta forma, se quiso prevenir cualquier intento de superar la percepción óptica -considerada como la única aproximación lícita a la obra- con la experiencia táctil. La prohibición cortaba por lo sano cualquier veleidad tendente a comprobar hasta qué punto el arte y la vida podrían intercomunicarse, hasta qué punto se podía experimentar el fluir de la vida en el arte. La fórmula ¡NO TOCAR! Era (y es aún) la consecuencia de privilegiar en la obra de arte la "imagen" sobre el "objeto"; la consecuencia, en fin, de subrayar su parte de irrealidad. Las imágenes, como es sabido, se diferencian del resto del mundo por algo fundamental: las imágenes no existen. "Tocar la obra" equivale a retrotraerla al estadio de objeto, atentando contra su esencia, que pertenece al orden de lo imaginario"3.

Otros artistas como Juan Muñoz sí ofrecerán la oportunidad de compartir el espacio físico que habitan sus obras, aunque esta vez las figuras no sean hiperrealistas. Ligeramente inferiores a la escala humana, monócromos, en ocasiones ausentes de rasgos, en otras deliberadamente histriónicos en sus gestos, los grupos escultóricos de Muñoz invitan al espectador a sumergirse en mundos paralelos, incómodos, silenciosos hasta el extremo de hacer consciente al visitante de su propia respiración y de la ausencia de ésta de aquellos a los que se acerca. El artista nos enfrenta así a la reflexión sobre la ilusión demiúrgica del hombre y sobre la exploración de espacios donde el espectador pierde su jerarquía, su posición de poder sobre el objeto, convertido no ya en observador sino en "intruso".

La capacidad de otorgar una vida imaginaria a las figuras humanas que encontramos a nuestro paso parece consustancial al ser humano, quizás porque desde pequeños, en nuestra infancia, así lo hicimos de la mano de nuestros juguetes. Pero los juguetes, como nosotros, crecieron, y alcanzan nuestra altura también en la madurez. Se supone, además, que con cierta edad no nos está permitido ya jugar con ellos. Sin embargo un impulso se mantiene, reprimido por nuestra educación, y desearíamos, aunque fuera por última vez, imaginar historias en las que incluir a los personajes que encontramos. El juego, y el juguete, convertido en actividad para adultos, guarda algo de grotesco, de anacrónico, de perverso, se asemeja al carnaval. El juego para el adulto supone una liberación y vuelta a la falta de responsabilidad del niño. Parece que el arte contemporáneo y sus artistas sean los únicos con licencia para una vuelta legítima al juego, a la configuración de muñecos, de entornos, situaciones y actitudes infantiles. La vanguardia, desde el dadaismo y fluxus hasta llegar a nuestros días, ha sabido utilizar el carácter subversivo de lo lúdico. Si Calder creó toda una serie de figurines para crear su mítico circo, Damien Hirst, a día de hoy, es aplaudido en su tenaz actitud infantil, de niño travieso, entrometido y provocador respecto a toda lógica madura. Convertido en un juego, tal y como nos avisa Gadamer, 
el arte es un territorio de inevitable re-conocimiento y autorrepresentación, una actividad que se vuelve sobre nosotros $\operatorname{mismos}^{4}$, una especie de espejo sobre el que reflexionarnos.

\section{La vida secreta del doble}

Lo que está en juego en todo este asunto es, después de todo, la eterna problemática de la capacidad de habitar en nuestros dobles. ¿Hay algo de nosotros en nuestras imágenes? ¿Realmente se nos roba el alma (o un poco de ella) cuando somos capturados en fotografías? ¿Hablamos, como ventrílocuos, a través de la marioneta o tiene ésta voz propia?

Las culturas antiguas suelen conceder una cierta carga mágica, de animación, a los dobles, bien sea en forma de muñecos o esculturas en los más diversos materiales y formas. Quizás, a pesar de lo mucho que ha acontecido, no hayamos avanzado tanto. Victoria Nelson en su The secret life of puppets no duda en señalar una vuelta a lo religioso en la obcecación contemporánea en "dar alma a lo material", señalando las similitudes entre el "creer" religioso y el "hacer creer" artístico ${ }^{5}$. Quizás, después de todo, el vacío que sufre el ciudadano occidental actual provenga del enorme número de imágenes y fotografías de sí mismo que han debilitado su "alma". Las identidades se construyen y exponen, se vierten en las imágenes colgadas en las redes sociales. Todo ello parece albergar una nueva clase de "animismo", la creencia mágica en la capacidad de la imagen de albergar nuestra identidad, nuestro espíritu, etéreo más que nunca, depositado en un código binario y la acumulación de píxeles.
El arte contemporáneo ha tenido en la regresión al origen (a lo primitivo y a la infancia) uno de sus principales objetivos. Dialogar con ese "otro" en forma de objeto parece suponer un modo mágico de alcanzar lo universal ${ }^{6}$. Sin embargo para alcanzar ese trascendentalismo se eligió la sencillez infantil. Tratando de ser lúdico e interactivo, sin duda el arte se ha acercado al juego, y por ello, a la hora de representar al ser humano ha vuelto en muchos casos a hacerlo en forma de muñeco, títere o maniquí, en ocasiones de forma alegre, en otras irónica, y en otras obsesiva, con la carga paranoica de las imágenes que se repiten en nuestro subconsciente desde niños.

La fascinación que ejerce ese "otro" adquiere, en muchas ocasiones, un tono oscuro y siniestro. El juguete, la marioneta y el maniquí producen la desagradable sensación de ocultar vidas atrapadas en lugares inhóspitos, vitrinas y escaparates de dudosa salubridad. Su posible insatisfacción nos afecta pues nos sentimos culpables de haberlos creado, de utilizarlos en nuestro provecho y después guardarlos en el armario o el trastero, desechándolos hasta su olvido. El muñeco y el maniquí suponen la cosificación máxima del yo, pues aunque tratemos de personificarlos, son, realmente, objetos, y como tales son tratados. Nosotros, sin embargo, asustados quizás ante la desagradable presencia de seres que albergan un vacío en su interior, tratamos de conferirles una identidad, tratamos de "animarlos", cumplir el deseo que nos permita conceder vida a lo inerte. 


\section{Modelos de arte}

Una de las primeras figurillas de maniquí que se nos viene a la cabeza es la del modelo humano que sirve para la obtención y estudio de diferentes posturas utilizadas como referente para el artista. Recurso básico de escuela de arte, esta figura nos asombra por su conseguida movilidad y liviandad. Algunos artistas interesados en la figura humana, por un lado; en el sentido pedagógico del arte, por otro; e incluso por la introducción del movimiento en la escultura, como Ángel Ferrant, tratarán este tipo de figuras y sus posibilidades, en pequeños maniquíes como Estudio esterotómico de coyunturas estatuarias (1940) y Mujer de Circo (1953). En ellas modelo de copia y obra se funden, extrañamente, creando una obra nunca concluida debido a un potencial movimiento que la convertiría en "infinita".

El arte contemporáneo va a ir introduciendo en su acercamiento a la figura humana la exploración de las posibilidades maquínicas o inorgánicas de la conformación del cuerpo, alejándose de la escultura tradicional, rechazando su estatismo y utilización de materiales nobles para tratar de dar movimiento a la misma. También, en parte, los artistas buscarán en este nuevo tipo de figuras de materia "inerte" la metáfora de unas vidas dirigidas por fuerzas superiores (poderes religiosos, políticos o económicos) que impiden la libertad y nos convierten en marionetas. En todo caso, el muñeco o maniquí se moverá como personaje entre la simpatía y el rechazo, entre el recuerdo infantil del fiel compañero de juegos, o el desequilibrio psicológico de la esquizofrenia. Casos ambos en los que los personajes de la imaginación han adquirido una sensación de presencia propia. El muñeco y maniquí suponen también una recuperación de antiguos debates sobre el carácter mágico de las figuras, capaces de funcionar como recordatorio del ausente o de materialización de lo espiritual. Los materiales utilizados para su realización entroncan con la tradición de la cultura popular, serán pobres y fáciles de manipular: cera, madera, trapo...
Desde las primeras vanguardias muñecos y maniquíes van a poblar las creaciones de muy diversos artistas, en algunos casos asaltando su propia vida privada. Debemos suponer incluso que estas figuras debieron ser bastante habituales como objetos de apoyo en los estudios artísticos, al menos si atendemos a su aparición junto a pintores en obras de Degas o Kokoschka. Será Giorgio de Chirico, sin embargo uno de los artistas más conocidos por la introducción de extrañas figuras entre el maniquí y la escultura en sus paisajes "metafísicos". La figura del maniquí crea una sensación intermedia entre la estatua clásica y el ser humano real, supone una asimilación esquemática que une ambas figuras.

Otravetaaficionadaalapresentación defigurasambiguasserálaexpresionista. En su incursión, en un camino cuyo origen estará en obras provenientes de la tradición "negra" de El Bosco a Goya, los pintores expresionistas como Munch, Ensor, Kirchner o Heckel harán de difícil distinción el monigote o la máscara del retrato real. El mundo contemporáneo, el de la masificación urbana y reducción del individuo a integrante de grupos sociales alienantes, asiste a la anulación de la identidad individual. En ellos la convivencia social es descrita con un carácter carnavalesco, habitada por hombres apenas convertidos en caricaturas de sí mismos. Si Goya ya había realizado una pionera y metafórica interpretación de El pelele, el alemán George Grosz introducirá figuras de autómatas en sus obras como modo de crítica social, de denuncia de la "mecanización" del ciudadano. José Gutiérrez Solana retrató de modo obsesivo muñecos y maniquíes, habitualmente en vitrinas. La inquietud que generan estas figuras se multiplica por su difícil distinción del resto de humanos, ambos estáticos, inertes e inexpresivos por igual, en un paralelismo desasosegante.

La fotografía será, no obstante, el medio que con mayor eficacia ha tratado de captar la atmósfera enrarecida creada por la presencia del maniquí. Así 
lo hará Eugente Atget en sus conocidas fotos de escaparates en la París de principios de siglo XX. La intranquilidad desencadenada por estas figuras no está provocada tanto por suponer una presencia fantástica, sino precisamente por la cotidianidad de la mismas. Atget consigue hacernos parar sobre los elementos siniestros que habitan en nuestro día a día, aún más resaltados por la extraña soledad de sus tomas de la gran ciudad, habitualmente bulliciosa, que imprime un tono onírico y fantasmal a sus imágenes.

Los dadaistas, debido a su posicionamiento tan crítico como lúdico, hicieron uso de muñecos y maniquíes de todo tipo en sus obras, pero fue sin duda la corriente surrealista la que, recogiendo la vía abierta por movimientos como el dadaista y las sugestivas imágenes de autores como Atget y De Chirico, se lanzó a la exploración de las posibilidades de muñecos y maniquíes en sus creaciones, dobles capaces de despertar la vertiente subconsciente de la mente humana. La referencia de la regresión psicoanalítica a la infancia suponía el principal sustento teórico al respecto. El maniquí (mayoritariamente el femenino) otorgaba a los artistas la posibilidad de enfrentarse a la figura de la madre, ese amor perdido de referencia edípica; y a la "amante-mantis", al miedo a la vagina castradora. Ofrecía la posibilidad de reconfigurar ambas figuras atendiendo a recuerdos y obsesiones en un mecanismo de vuelta catárquica a la infancia. Como modelos permiten una liberación de las ataduras de la lógica. Son cuerpos sin mente ni razón, mera presencia física inconsciente. Como figuras del deseo serán, además, capaces de expresar los anhelos sexuales reprimidos por esa sociedad burguesa y conservadora.

Muchos autores han calificado esta utilización del maniquí por parte del grupo surrealista como un un ejercicio superficial, casi antecedente pop, que no conseguiría sacar provecho a las posibilidades abiertas por su figura ${ }^{7}$. Sin embargo, y a pesar de lo liviano de su propuesta, el maniquí seguirá siendo un elemento muy utilizado a lo largo del tiempo por artistas continuadores de la influyente estela de los hallazgos surrealistas. En este sentido, una de las vías más preciadas abiertas por el maniquí sería la de la posibilidad de ejercer deseos reprimidos (sexuales u homicidas) en su figura. El artista conseguía así alimentar su imaginación incluso en todo aquello que en el mundo y en la sociedad real sería tachado de aberrante o criminal. Si la libertad es imposible debido al pacto social cimentado bajo los mecanismos de la educación, la moral y la ley, el maniquí ofrece, por su lado, un modo de liberación de los instintos. Lo experimentado con el cuerpo del doble en forma de maniquí no debe causar trauma ni arrepentimiento debido a su categoría de simulacro inerte. El maniquí no sufre, no habla, ni se queja, y, por supuesto, no muere. Este punto extremo será explorado con enormes dosis de ironía y humor negro por Luis Buñuel en su magnífico Ensayo de un crimen (La vida criminal de Archibaldo de la Cruz, 1955). En la película, el protagonista llegará a ejercer sus fantasías homicidas de la mano de un maniquí que es copia de la mujer de carne y hueso a la que desea. Gracias a ello su impotencia a la hora de realizar semejante acto en el mundo real se ve saciada por el "asesinato" de la muñeca. El arte actúa así como método de liberación de deseos reprimidos gracias a la simulación de acciones que no ocurrirán en la vida real pero que podemos vivir gracias a la experiencia estética. De todos modos si hay fantasmas que exorcizar será necesario entender por qué éstos aparecieron en nuestras vidas. A este respecto Pilar Pedraza se pregunta:

"[...] las muñecas rotas, maltratadas, pisoteadas, acuchilladas, mordidas y luego, por si fuera poco, fotografiadas, enmarcadas e inauguradas con 
canapés, no mandan al artista a la cárcel, porque, obviamente, ni la palabra perro muerde ni el maniquí deja de ser un fantasma. Pero hay que estudiar los fantasmas para entender por qué estamos siempre tan asustados"8.

Uno de los roles básicos del maniquí es el de servir como modelo sobre el que colocar ropas, sustituto humano en las labores de confección de prendas, así como en su venta, en los escaparates de las tiendas. El maniquí observa la calle, nos observa, generando una extraña sensación, en ocasiones aumentada por su composición fragmentaria o por su enigmática ausencia de rasgos. Y sentimos la curiosidad de descubrir si tras la ropa encontraremos un cuerpo o tan sólo una estructura de metal o madera. Es posible encontrar un buen número de fotógrafos que se fijarán en el maniquí como presencia recurrente. Entre ellos destaca sobremanera uno de los grandes nombres de la fotografía publicitaria y de moda: Helmut Newton. Él nos ofrecerá alguna de las instantáneas más brillantes en la contraposición de modelos humanas y maniquíes, a modo de espejo. Convertidas en objetos al servicio tanto del fotógrafo como de los intereses mercantiles de las firmas, las modelos en poco se diferencian de sus "dobles". Eso sí, ambas deben suscitar el deseo del público, provocar una reacción en él a través de un sutil erotismo, basado en la atracción que provoca su belleza fría e inerte.

Charles Ray, uno de los artistas más empeñados en la plasmación de la figura artificial del ser humano, presentará un discreto maniquí masculino desnudo en Male mannequin (1990). La novedad en él será la de ofrecernos un cuerpo al completo y de manera bastante realista, algo no habitual puesto que el maniquí suele reducirse a un esquema en que no se trabajan las partes ocultas por la ropa por simples motivos de economía de medios. Por otro lado Charles Ray incidirá en varias instalaciones en la contraposición del cuerpo real con el artificial, haciendo un juego irónico en el que no sabemos si el cuerpo real se encuentra en plena metamorfosis a lo artificial o el metal está cobrando vida. En estas instalaciones la objetivización del cuerpo es plasmada ya con una presencia corporal real, de carne y hueso. Ray parece querernos hacer partícipe del difícil cometido del modelo artístico, sometido a un esfuerzo de estatismo. Al mismo tiempo nos dispone a reflexionar sobre la necesaria "petrificación" del ser humano, en el sentido de solidificación matérica y anulación del movimiento, que hay tras sus representaciones artísticas.

Utilizado por Thomas Hirschhorn podemos ver cómo el maniquí se afirma finalmente y sin complejos como material artístico. Según este artista es además un material capaz de reflejar a la perfección nuestro tiempo: fabricado en serie, es producto industrial y de consumo; es, de alguna manera, democrático y perfectamente reconocible por cualquier espectador. El maniquí permite la valoración del "otro" al mismo tiempo que la reflexión universalizante. Quizás Hirschhorn sea el artista más decidido a defender el doble carácter de autorretrato y retrato universal de un maniquí donde tanto el artista como el espectador se proyectan y de alguna manera se funden. En sus propias palabras: "Los Maniquíes son una forma "sin cabeza" de mi prójimo, una forma que doy al otro fuera de mi mismo. Un Maniquí representa la más pequeña distancia entre yo mismo y la imagen del otro. Un Maniquí es otra forma de mi mismo. Es una superficie donde me proyecto"9. 


\section{Fuera de escena}

Uno de los problemas principales a los que nos enfrentamos a la hora de repasar la figura del maniquí en la historia del arte contemporáneo será el de topar una y otra vez con figuraciones femeninas del mismo, realizadas además desde una óptica fuertemente patriarcal. Algunos autores, como Pilar Pedraza, no dudarán en afirmar el carácter misógino de estas creaciones ${ }^{10}$, basadas en una tradición cultural muy arraigada a través de perspectivas religiosas que otorgan a la mujer una posición secundaria respecto al hombre. Mientras la Biblia la retrata como creación derivada del segundo a partir de su costilla; la literatura y demás narraciones culturales (mitos, cuentos...) habrían arrastrado ese lastre de una condición negativa de la mujer, en todo caso una creación del hombre, a su imagen y semejanza y siempre a su merced y disposición según sus necesidades. Desde el propio mito de Pigmalión a obras como El hombre de arena de E.T.A. Hoffman (1817) o La Eva futura de Villiers de L'Isle-Adam (1886), todos los relatos no habrían sino alimentado esa misoginia y relegación del papel de la mujer a objeto asociado a lo malévolo ${ }^{11}$.

El surrealismo no habría frenado esta corriente y, de la mano de su perspectiva masculina, habría explorado la construcción de la mujer a partir de la liberación de los deseos sexuales, reprimidos desde la época infantil. La pulsión contenida desde entonces provocaría una inevitable fascinación por ese "otro" (mayoritariamente otra) y la derivación hacia unos traumas psicológicos con origen en el abandono (o expulsión, según se mire) del vientre materno.
No obstante la misoginia irá siendo relegada y se irá decantando en favor de una visión cada vez más compleja y matizada de la figura de la mujer. Esta complejización llevará a incidir en territorios ambiguos, en una tendencia radicalizada de la vía abierta por el surrealismo que derivará hacia la investigación de nuevos conceptos como la abyección ${ }^{12}$ y la obscenidad. Este viraje vendrá de la mano de la incorporación de la mujer a los diferentes ámbitos sociales y políticos, así como a la creación artística, sobre todo a partir de mediados del siglo XX. Así, por primera vez, la figura femenina pasará a ser ya una construcción controlada por creadoras féminas.

El camino contrario al establecido previamente obligaba a la muestra pública y reivindicación de todo aquello que provocaba el trauma, y, por tanto, había sido oculto, en el rol femenino. La mujer, de este modo, procuraba la liberación de los estigmas sociales que habían conducido a que gran parte de sus características identitarias fueran calificadas como desagradables o sucias (de la menstruación al parto). La mujer ni era malévola ni débil, y ahora sí estaba dispuesta a recuperar las riendas de la construcción de su imagen, un hecho hasta entonces alejado de su ámbito de poder. Si históricamente había sido relegada y mantenida "fuera de escena", su nueva posición le permitía introducir imágenes y temáticas hasta entonces fuera de debate y representación.

Hans Bellmer, cercano a los surrealistas, admitirá tempranamente esa tendencia a la construcción de figuras ideales de mujer a partir de los deseos masculinos ${ }^{13}$. Este reconocimiento le conducirá hasta una creación

10. PEDRAZA, P.: Máquinas de amar: secretos del cuerpo artificial. Madrid, Valdemar, 1998, p. 32

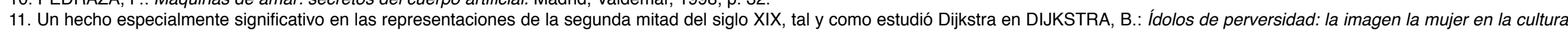
de fin de siglo. Debate, 1994.

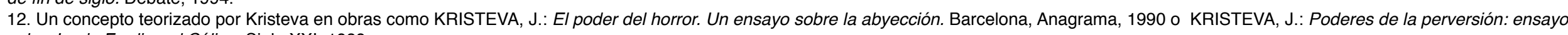
sobre Louis-Ferdinand Céline. Siglo XXI, 1989.

13. BELLMER, H.: Anatomía de la imagen. Barcelona, Ediciones de La Central, 2010, p. 26. 
que reunirá gran parte de sus obsesiones personales y artísticas: la muñeca (die puppe, 1934). En ella Bellmer volcará su tendencia a la creación de un cuerpo compuesto de partes intercambiables, de un modo literal y metafórico. Concebirá un cuerpo en constante metamorfosis, además con toda una reflexión teórica al respecto que refuerza el carácter nada azaroso de su búsqueda. La puppe de Bellmer abre un camino interesantísimo que permite al artista conformar una figura deseada pero fuera de toda estandarización social. La muñeca de Bellmer huye de la normalidad y deja paso al lado "monstruoso" que puede habitar en nuestra imaginación. Tras sus deconstrucciones y recomposiciones del cuerpo el artista se asemeja al niño, empeñado en descubrir el secreto tras la primera apariencia de las cosas, en buscar una verdad que intuye oculta. Según Bellmer el cuerpo de la muñeca es "comparable a una frase que nos invitara a desarticularla, para recomponer, a través de una serie de anagramas infinitos, sus verdaderos contenidos"14

Bellmer había conseguido alcanzar una creación fascinante que mostraba aquello que el buen gusto artístico había rehuido tanto estética como socialmente y de lo que, sin embargo, el espectador era incapaz de abstraerse. Lo obsceno, aquello habitualmente apartado de la vista por la tradición cultural, la ley o la moral, entraba a formar parte así de las posibilidades artísticas. El arte encontró un nuevo lugar por el que mostrar al público aquello que le era desagradable, pero enigmático e inquietante, que atraía tanto como provocaba repulsión. El arte obligaba (o más bien incitaba) al público a mirar. Por primera vez la construcción del cuerpo femenino no atendía al placer de la idealización de la belleza, sino que ofrecía la vía opuesta, la de la visibilización de la deformación, de la distorsión de la norma.
Marcel Duchamp entendió a la perfección estas premisas, llevándolas a su máxima expresión en Étant Donnés (1946-1966). En ella hizo confluir la construcción obsesiva del cuerpo femenino en forma de maniquí con la voluntad de "mirón" del espectador. Étant Donnés es una instalación que empuja a acercarse a aquello que está oculto, fuera de escena, haciendo partícipe al espectador de una situación incómoda y desagradable. La instalación de Duchamp enfrenta al espectador a la sexualidad y la violencia, terrenos ambos en que la mujer ha sufrido tradicionalmente una posición de inferioridad, de sufridora, alimentada por el silencio social. Pero el silencio o la ocultación no suprime el problema, tan sólo lo convierte en un tabú conocido pero no expresado. Con la instalación, Duchamp arrastraba al espectador a una difícil posición, evitando que la distancia se convirtiera en exención de responsabilidad. La mirada se afirma activa, un hecho además subrayado por la necesidad de hacer uso de la mirilla, no de recibir una imagen sino ir a ella, buscarla. Duchamp activa así el deseo de formar parte, de ver, de construir espacios sólo terminados cuando el espectador los experimenta.

Todo lo magistralmente insinuado por Bellmer y Duchamp será recogido en los últimos años al fin por una mujer, la fotógrafa Cindy Sherman. Acostumbrada a ser la propia protagonista de sus creaciones, en que juega con la identidad propia y la construida socialmente gracias a la imagen, como había hecho el propio Duchamp en su personaje de Rrose Selavy. Sherman, cuando optó por distanciar su cuerpo y dejar de ser protagonista de sus proyectos, se decidió a incorporar la figura del "doble" en forma de maniquí. Sherman recoge toda la carga de obsesión sexual y de muestra explícita de lo desagradable para elevar a la máxima potencia el terreno de lo obsceno, incorporando incluso aquello abyecto. Lo desagradable ya no será sólo una cuestión formal sino que llevará la imagen hacia la muestra de lo putrefacto, 
aquello que parece oler mal, aunque fuera fotografiado en otro lugar y otro tiempo. Cindy Sherman concebirá así Sex pictures (1989-1992). Explícita hasta lo grotesco, la serie se basa en fotografías de maniquíes construidos a partir de diferentes piezas, no siempre coherentes entre sí, y en ocasiones dejando sus figuras fragmentadas. Los maniquíes suelen formar posturas manifiestamente sexuales, opresivas en su composición en planos muy cerrados y entornos claustrofóbicos. Sex pictures anula toda posibilidad de satisfacción del deseo del espectador, convirtiendo al maniquí en la inversión del modelo comercial o surreal, el reverso oscuro, molesto y repulsivo, el lado pesadillesco de la fantasía sexual. Quebrado, desvencijado y sucio, el maniquí pierde todo su sex-appeal. Sherman lleva a la práctica artística así las posibilidades de recuperación del control de la identidad ofrecidas por las teorías de Judith Butler. En ellas se analiza la posición impuesta tradicionalmente a la mujer y la subversión de la misma ${ }^{15}$. El género y el sexo serán, a partir de entonces, un territorio de "disputa" abierta.

En una vuelta a su instalación física, a su presencia directa ante el espectador, el maniquí ofrecerá para la artista Paloma Navares la oportunidad de reflexionar sobre los procedimientos de construcción de una identidad y un cuerpo femenino artificial. Navares advierte de la conversión de la mujer contemporánea, gracias a los avances de la cirugía estética, el maquillaje y demás productos de belleza, en un ser protésico, de piezas reemplazables. Sin embargo la artista, desde una perspectiva pesimista, no concede a este hecho las posibilidades de control de la imagen. Milenia, del corazón y el artificio (1998) es una instalación que presenta un maniquí en un entorno aséptico y plastificado, similar al del quirófano o el centro comercial, una metáfora sobre un cuerpo construido según exigencias del mercado y completamente dependiente de la imagen superficial.

Todo esto nos lleva a la identificación de mujer y muñeca como creación artificial, además, como construcción con una pretendida carga sexual, un objeto (también sujeto) del deseo ${ }^{16}$. Lo sorprendente será esta unión de ámbitos en principio contrapuestos en el rol de una mujer que terminará por convertirse de esta manera en "muñeca viviente". El modelo de mujer proyectado por los medios tendría así una enorme carga sexual modelada desde la niñez y agresivamente publicitada desde la construcción de muñecas como Barbie, canon de belleza y referente social de una mujer tan superficial como artificial. La artista Chris Jordan no dudará así en relacionar el auge de las operaciones estéticas con la norma marcada por la muñeca en su obra Barbie Dolls (2008) ${ }^{17}$. Según Walter: "La asociación entre la feminidad y el atractivo sexual empieza muy pronto. No es ninguna novedad que las mujeres quieran ser sexualmente atractivas, pero sí lo es que hasta los juguetes infantiles tengan que resultar sexy"18.

\section{La duda}

Si realmente el mundo se ha convertido en un espectáculo, necesitamos de dobles especializados que nos reemplacen en "escenas de peligro", tal y como es habitual en el cine; o bien, si el mundo es un simulacro, necesitamos imágenes similares a la nuestra que nos echen una mano frente a la virtualidad de semejante entorno. El doble es, sin duda, un objeto de enorme

15. Teorías analizadas en obras como BUTLER, J.: El género en disputa: el feminismo y la subversión de la identidad. Paidós, 2013.

16. BUTLER, J.: Sujetos del deseo: reflexiones hegelianas en la Francia del siglo XX. Amorrortu, 2012

17. En una imagen del torso de una mujer formada por 32.000 barbies, el mismo número que el de operaciones de aumento de pecho realizadas en EE.UU. tan sólo en el año 2006. http://www.chrisjordan. com/gallery/rtn/\#barbie-dolls (consultado el 05/10/2014).

18. WALTER, N.: Muñecas vivientes: el regreso del sexismo. Madrid, Turner, 2010, p. 14 
ayuda, aquel que sufre el accidente y permite que no haya sangre ni heridos reales. $\mathrm{O}$ bien permite simular situaciones que nos conceden la posibilidad de aprender sin que los errores que podamos cometer pasen a mayores, tal y como ocurre en las prácticas médicas con maniquíes. Incluso si la situación es plácida hay dobles dispuestos a otorgarnos un descanso, como el del piloto automático en el caso de la aviación. A pesar de estas innegables utilidades, el doble genera siempre esa sensación siniestra de "realidad", de sufrir el accidente, de sufrir también por su posición secundaria, sustitutiva. Siempre nos queda la duda y la figura parece cobrar vida, tener un aliento que nos sorprende e inquieta. Puesto todo en entredicho existe muy poca diferencia ontológica entre copia y modelo. Dudamos tanto de que los dobles estén vivos como de que los vivos estén hechos de materia inerte.

Ante semejantes dudas existenciales existen diferentes modos de enfrentamiento, de lo trágico a lo cómico. Incluso las verdades en mayúsculas son puestas en entredicho, y la historia y la ciencia, como cualquier otra cosa, deben ser tratadas como construcciones. Aceptado el hecho sólo podremos mirar con escepticismo el relato de verdad del museo, apoyado en re-construcciones más o menos agraciadas de los hechos. Guillaume Bijl asimilará de esta manera museo de historia o ciencia con museo de cera, escaparates comerciales ambos habitados por maniquíes más o menos conseguidos. Así mostrará instalaciones como su The Concise History of Prehistoric Man (1996), toda una burla a la simplificación histórica de hechos complejos, convertidos en leyendas de difícil constatación y dudoso gusto estético.

La duda, ampliada a la realidad al completo, hará entender la enorme capacidad de simulación tanto de las imágenes artísticas como de las no artísticas. Por ello la hiperrealidad aparente que encontramos en las calles en nuestra vida diaria se hace indistinguible de la hiperrealidad de la imagen artística. Como nos avisó Baudrillard el simulacro carece de la necesidad de un modelo que copiar, y apunta hacia la existencia por sí mismo. La amenaza no es la copia. Puesto que, una sociedad donde todo se convierte en producto, y, aún más, donde lo único importante del producto es su envoltorio, como bien nos enseñó Andy Warhol, nos convierte en estúpidos turistas que no miran, sino que hacen fotografías, confían en la copia sin atender a un modelo original que termina perdiéndose en el olvido, disolviéndose. La obra de Duane Hanson permite reflexionar a este respecto. Sus monigotes provocan el equívoco, como nos demuestra la fotografía de Sharon Lockhart que retrata el montaje de la instalación: Lunch Break installation, "Duane Hanson: Sculptures of Life" 14 December 2002- 23 February 2003, Scottish National Gallery of Modern Art (2003). La copia ha adquirido el nivel de facsímil ${ }^{19}$. Ya no sabemos quién respira y quién no en la exposición, quién es obra y quién espectador. Pero, ¿qué más da? Ambos nos demuestran que no hay contenido tras la superficie. Según Charo Crego: "Como sucede en otros ámbitos del mundo postmoderno, en el que las copias de la realidad parecen independizarse de la propia realidad, el maniquí ha adquirido perfiles tan nítidos y características tan perfectas que ya no refleja, sino que sustituye al hombre." 20 .

\section{El muñeco somos nosotros}

Pero si realmente compartir un espacio común con maniquíes, autómatas o títeres nos inquieta es porque nos sentimos cercanos a ellos. Su posición, sus preocupaciones, sus movimientos torpes y reducidos, son, después

19. CREGO, C.: Perversa y utópica: la muñeca, el maniquí y el robot en el arte del siglo XX. Madrid, Abada, 2007, p. 239.

20. Ibídem, pp. 231-232. 
de todo, los nuestros. Los sentimos próximos, nos identificamos con ellos. Nos preocupa su estado porque, en última instancia, nuestro gran dilema es admitir que no somos muy diferentes. La efectividad del teatro de marionetas, aún persistente a pesar de todas las posibilidades técnicas actuales, proviene de la fuerte presencia de sus figurillas. Las marionetas son extensiones de nuestro cuerpo, nos ofrecen la posibilidad de escribir con ellas nuestra autobiografía. Nos liberan del mismo modo que nos hacen entender los peligros de ser controlados por fuerzas superiores. Tememos convertirnos en títeres, tememos ser los Cesares del Doctor Caligari o la María de Metrópolis, convertirnos en dobles que se mueven de forma ajena a su voluntad. Las marionetas y los muñecos nos fascinan, nos ofrecen la ilusión de control sobre un mundo a pequeña medida donde vertemos nuestros deseos, donde nada escapa de nuestro control y desbarata nuestro plan. El teatro de marionetas, anacrónico y romántico a día de hoy, ofrece aún una salida frente al fracaso social, tal y como le sucede al protagonista de Cómo ser John Malkovich (Being John Malkovich, Spike Jonze, 1999), un inadaptado que vuelca sus habilidades en la construcción de figurines en que fantasear con los éxitos de su pequeño avatar. Tras la marioneta se esconde también el miedo a la escisión de la identidad, a la caída en la esquizofrenia, en la escucha de voces ajenas que nos dominen ${ }^{21}$, como tan bien retrata Tony Oursler en sus conocidas obras.

Tras todo lo dicho se esconde el deseo imposible de ser otro, de ser mejor, ser querido, respetado, amado. Somos nuestras propias marionetas, nos autoconstruimos con la esperanza de ser aceptados y formar parte del espectáculo. Portamos una máscara que ha sido, además, configurada con la ayuda del arte. Tras ella quizás se encuentre un ser humano. El artista crea máscaras, aspirando paradójicamente a desvelar al que se oculte tras ella. De Dalí a Orlan parece que gran parte del trabajo del artista sea el de cultivar una imagen superficial que una obra y persona.

Aeste respecto nos encontramos, por último, al maniquí definitivo de nuestros días: el creado por Narcissister ${ }^{22}$. Este personaje, alter ego realizado a medida por una artista neoyorkina, lleva a su máxima expresión todas las posibilidades y peligros de habitar una sociedad del espectáculo, de los medios, de lo tecnológico, la globalización e internet. En ella la identidad se afirma en las imágenes que reproducimos de nosotros mismos (fotografías, vídeos...) en espacios escénicos donde controlamos el atrezo, maquillaje e interpretación. Ya que habitamos un mundo de la imagen, y hasta nuestra vida privada es aireada por propia voluntad en imágenes, no hay respiro a la actuación del personaje y nos convertimos más que nunca en maniquíes, muñecos, autómatas..., permanentes y dependientes de lo que se quiere de nosotros o de lo que pretendemos de nuestra proyección en un yo virtual, ficticio. El artista, más que ningún otro, siente esa necesidad de ser original aunque para ello tenga que esconderse tras una máscara que oculte las miserias de su existencia mundana.

Narcissister ahonda en todas estas cuestiones. Para ello propone una objetivación del ser humano llevada a la exageración absoluta. Recrea una identidad ficticia que caricaturiza el mundo artístico y del espectáculo. Tan sólo una máscara es necesaria para crear un nuevo maniquí-humano, un personaje grotesco basado en la proyección de clichés sociales y artísticos. Narcissisteres una construcción, un rol artístico con el que identificarse como creadora, como personaje y una marca registrada al mismo tiempo. Para ello se vale de los métodos de la industria de masas hasta ridiculizarlos y hacer ver su lado más extravagante y kitsch. Otros muchos artistas ya habían

21. NELSON, V.: The secret life of puppets. Cambridge, Mass., Harvard University Press, 2001.p. 252.

22. Para más información sobre la artista véase http://www.narcissister.com/about (consultado el 05/04/2014). 
entendido la necesidad de creación de identidades artísticas y públicas, en ocasiones muy difíciles de separar de lo privado. Warhol quizás sea el referente principal al respecto. Las Guerrilla Girls lo hicieron con el propósito de mantener una lucha social, no identificable a nombres o rostros propios. Otros, en los últimos años, han tratado de construir personajes públicos entendidos plenamente como máscara y maquillaje, como es el caso del rockero Marylin Manson. El artista callejero Banksy consigue algo parecido ocultando su identidad y exaltando su personalidad artística a partir de ese misterio.

Quizás con la experiencia de esos ejemplos, Narcissister se decide a encarnar un rol abiertamente caricaturesco que preserve de alguna manera su privacidad y hasta su rostro real. Para la propia artista la creación del personaje supondría una manera de protección de ese lado privado. En sus propias palabras: "I knew that when I started Narcissister, first of all, that I wanted to protect myself to a certain extent, that I wanted to protect my privacy and that I wanted to believably portray this character, Narcissister, and through her portray many other characters" 23 .

Narcissister celebra y critica esa tendencia del artista contemporáneo a erigirse como figura superficial, mera imagen. Para ello da vida a un maniquí, convierte al artista en maniquí. De hecho se inspiró en la figura de la muñeca y el maniquí, figuras que ya había tratado previamente en su obra: "[...] I also started working with mannequins, obviously. I was spending a lot of time around these life-sized dolls, dressing them, creating scenarios for them, and I started to own a few mannequins myself because the companies would give them to me or I would find them. I found I had a real affinity for mannequins. The first piece I made as Narcissister was The Mannequin. It led me to be a doll-like figure myself, as a character, to use that mask. Also a lot of my gestures as Narcissister are doll-like. I love having a lot of stillness where you have this illusion of Narcissister being a doll"24.

Desde su propio e irónico nombre, acepta y se burla de esa necesidad narcisista del artista y del ciudadano actual de verse una y otra vez, de contemplarse complacido en sus imágenes. Como nos avisa Gabriel Albiac: el deseo es, inevitablemente, onanista ${ }^{25}$. Pues, ¿quién ve más que uno mismo sus propias imágenes colgadas en facebook? Aspiramos a ser nuestros mejores admiradores. Aspiramos a ser dignos de nuestra propia admiración. Nuestras imágenes son, más que nada, espejos. Toda esta necesidad masturbatoria es abordada por la artista en su proyecto Selfgratifier, instalación que muestra una maquinaria dirigida al propio placer a medio camino entre las construcciones dadaistas o el absurdo de las máquinas de Tinguely y el retrato cómico del gimnasio y la cultura del bodybuilding.

Narcissister, dando definitivamente vida al maniquí, afirma nuestra identidad como títeres de un show de dudosa calidad. Consigue llevar a la máxima fusión y confusión el mundo elitista del arte y la cultura de masas. Ironiza sobre el posicionamiento político del artista de vanguardia, transgrede irónicamente el feminismo, celebrando y criticando al mismo tiempo el mundo del espectáculo y el arte. La artista actúa tanto en círculos reducidos de arte de acción y danza como aparece en revistas y programas comerciales ${ }^{26}$. Con

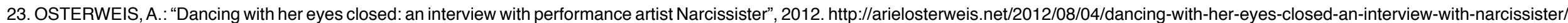
(consultado el 05/04/2014)

24. Ibídem.

25. ALBIAC, G.: Caja de muñecas: figuras de la concepción inmaculada. Barcelona, Destino, 1995, p. 49

26. BROWNING, B. y OSTERWEIS, A. : "Dancing Social", Theatre Survey, vol. 53, n² 2, 2012, p. 271 
ello parece querer rehuir del elitismo del arte contemporáneo y ahondar en sus inevitables relaciones con la cultura de masas. Adopta así una posición coherente y "profesional" en que, atendiendo a los diferentes rangos de los encargos, recibirá un trato socio-cultural y un salario diverso.

\section{Conclusiones}

Narcissistercompone una certera caricatura de la sociedad de nuestro tiempo, de la necesidad de autoconstruirnos a través de la imagen. Expone nuestra regresión al mundo infantil, a la risa grotesca de la máscara, al comentario vacío y a la actitud ingenua. La artista lleva al absurdo la obsesión por la construcción de cuerpos sintéticos, prototipos tendentes a la plastificación que nos acercan más a la artificialidad. Partiendo de esos cánones de belleza alcanzará su reversión, creando monstruos de varias cabezas, personajes inquietantes que muestran varias caras y posiciones posibles, como si de un truco de magia se tratara. Consigue llevar así lo obsceno y abyecto al público de masas, aumentando si cabe su influencia y carácter transgresor.

La artista se alimenta también del carácter lúdico de los elementos extraordinarios que presenta. Nos acerca al burlesque y al espectáculo de feria, al freak show. Con ello parece afirmar que nos hemos convertido en nuestros propios juguetes, en nuestro propio entretenimiento, en nuestra propia muñeca hinchable con la que satisfacer el deseo. Somos víctimas de un peligroso egocentrismo que nos ha aislado de los demás, nos ha hecho solitarios y engreídos, nos lleva a vivir en la eterna pose de la sonrisa forzada. Semejante mueca sólo puede mantenerse con la ayuda de una máscara, un maquillaje permanente que oculte nuestros miedos e insatisfacciones.
Quizás por ello la construcción del propio personaje de Narcissister intenta, en su ambigüedad, alimentar el debate y borrar barreras entre el "yo" y el "tú" ${ }^{27}$. No es una artista, somos todos, un hecho que se hará explícito en su proyecto Narcissister is you!, en que propone que diferentes personas en los más diversos contextos hagan uso de su máscara y se conviertan en ella. De este modo se hace una invitación a invadir una personalidad ficiticia, creada, accesible a todos. Se nos permite ser obra artística y, hasta de algún modo, convertirnos en artistas con el simple hecho de portar su imagen. Como trabajadora del arte, la artista está tan en venta como su obra, en forma de máscaras. Así desvela las relaciones económicas ocultas tras la construcción de personalidades ficticias y "consumibles", tanto en el mundo del arte como de la vida real.

Narcissister es una inteligente y autocrítica continuación de un gran número de hallazgos artísticos que provienen de las primeras vanguardias. La artista bebe $\sin$ reparos de la actitud provocativa dadaista, del cinismo metaartístico de Manzoni y la búsqueda de los límites del cuerpo iniciados desde el advenimiento del body art. Supone también un posicionamiento político descendiente del activismo artístico instalado desde mediados de siglo XX. Eso sí su posicionamiento es ambiguo, entre el activismo y la parodia. Asistimos así a un ejercicio de desmontaje de las impuestas separaciones de género y raza, a una aplicación deliberadamente superficial y sui generis de algunas de las teorías feministas, de Haraway a Butler.

Todo esto para dar otra vuelta de tuerca a las posibilidades de la comunicación a través de la imagen artística. A la interacción de artista y público, a la inevitable confluencia del mirar y ser visto, al intercambio de roles entre autor y espectador que permita experimentar nuevos puntos de vista con los 
que conocer al otro, el entorno que nos rodea, y conocernos así a nosotros mismos. Ello para tratar de alcanzar un objetivo final, si aún a día de hoy tal meta pudiera plantearse: una identidad propia. Eso sí, una identidad tan individual como colectiva, tan diferenciadora como homogeneizadora. Teledirigidos por nosotros mismos, vivimos en la lejanía de las imágenes en que nos proyectamos. Mantenemos nuestra esperanza de "ser" habitando en la inmaterialidad de la información digital, en sistemas globales que terminan por diluirnos en un todo.

Reducido el ser humano únicamente a imagen ha terminado por convertirse en un ser imaginario. Es ahí donde arte y realidad inevitablemente se cruzan, y es ahí donde los artistas deben ayudarnos a encontrar las claves para reconducir la situación y hacer de semejante circunstancia un campo abierto a las posibilidades creativas de autoconstrucción. Muchas son las dudas pues, hoy más que nunca, de la mano de las posibilidades ofrecidas por las redes de comunicación social, las identidades, reducidas a imagen que llevar puesta, se compran, tanto en la tienda de regalos del museo como en el centro comercial más cercano. Asumido que tenemos mucho de maniquíes, aún nos queda entender al servicio de qué o quién estamos actuando. 